\title{
Research on Informatization Strategies of Education and Teaching Management in Higher Vocational Colleges in the Era of Cloud Computing and Big Data
}

\begin{abstract}
Xiaozheng Yang
Xuzhou Vocational College of Bioengineering 221006

Abstract: At present, with the development of information technology, cloud computing and big data have been integrated into various industries in society, and they also have a relatively prominent performance in education and teaching management. The greatly enhanced efficiency of education and teaching information management in universities is a sustainable future for universities. The inevitable choice for sending letters. This article studies and discusses the informatization strategy of education and teaching management in higher vocational colleges in the era of cloud computing and big data, hoping to provide some useful suggestions for the development of higher vocational education in our country.
\end{abstract}

Keywords: Higher Vocational College Education and Teaching Management; Cloud Computing; Big Data; Management Informatization.

With the rapid development of our country's economy and the continuous innovation of science and technology, more new requirements have been put forward for the education and teaching model of colleges and universities, but the actual teaching management will be limited by traditional teaching concepts and hardware infrastructure, which greatly affects. The healthy development of universities. Combining many years of experience in education management in higher vocational colleges, the author combines cloud computing and big data technology in the new era to explore the reform measures of education and teaching management information in higher vocational colleges, aiming to comprehensively promote the process of education and teaching informatization in colleges and universities, as a higher education system, the transformation provides more possibilities.

\section{Common problems in the informatization of education and teaching management in higher vocational colleges}

Higher vocational colleges are the complement and extension of our country's higher education, and they have trained many outstanding professional and technical personnel for the construction of our society. In recent years, with the expansion of higher vocational colleges, the number of students has increased sharply, which has brought huge pressure to school education and teaching management. Therefore, higher vocational colleges urgently need to realize teaching information management and use information technology to upgrade the colleges. The efficiency of management, build a healthier learning environment for students. However, in the specific practice process, many problems have appeared, which have seriously affected the informatization process of education and teaching management. The typical ones are as follows:

1.1 The education and teaching management software of higher vocational colleges needs to be updated, and the practicality is not strong

According to the current survey data, many educational and teaching management software in higher vocational Copyright $\odot 2020$ Xiaozheng Yang

doi: 10.18282/le.v9i7.1497

This is an open-access article distributed under the terms of the Creative Commons Attribution Non-Commercial License

(http://creativecommons.org/licenses/by-nc/4.0/), which permits unrestricted non-commercial use, distribution, and reproduction in any medium, provided the original work is properly cited. 
colleges are basically purchased directly from software development companies, but due to funding constraints, the software content lacks personalized settings. In addition, in addition to the lack of the school's own characteristics, with continuous development, many contents in the information management software need to be modified. However, due to the lack of timely updates, the efficiency of the school information management system is getting lower and lower, and the practicality is straight. The decline has seriously affected the teaching management of the journey of higher vocational colleges.

\subsection{The education and teaching management information system of higher vocational colleges is not perfect}

With the continuous advancement of China's informatization process, many higher vocational colleges have made considerable progress in the informatization construction of education and teaching management, but only achieved a specific informatization teaching management system from " 0 " to " 1 " The construction is not perfect enough, and the relevant rules and systems of internal management still need to be explored by the school itself. If higher vocational colleges only meet the current situation without further rectification and improvement, it will have a great impact on the future development of higher vocational colleges.

\subsection{Higher vocational colleges do not pay much attention to the information management of education and teaching}

Nowadays, most domestic enterprises have basically realized informatization management, but college education and teaching informatization management is still in the preliminary stage of development. The significant difference between the two lies mainly in the degree of attention paid by managers. Compared with domestic enterprises, due to the limitation of their own development funds, higher vocational colleges have obviously insufficient investment in the negative side of information management, and they have not been able to feel the intuitive benefits of information management, which makes the management of higher vocational colleges The incomplete understanding of informatization education management has seriously hindered the process of informatization management construction in higher vocational colleges.

\section{In the era of cloud computing and big data, higher vocational colleges education and teaching management information implementation strategy}

\subsection{Enhance the importance of higher vocational colleges to the informatization of education and teaching management}

In the current era of big data, the leadership of higher vocational colleges should strengthen the importance of the informatization of education and teaching management, gradually introduce cloud computing technology and big data technology into it, and build a more complete education and teaching management system. First of all, the major vocational colleges across the country should establish a good exchange and interaction mechanism, learn from each other's excellent information construction experience, and gradually improve the efficiency of education and teaching information management in our country's vocational colleges. Secondly, combining the actual teaching situation of higher vocational colleges, combining advanced information technology with teaching practice, clarifying the goals of hardware facilities and software development in the school, and solving practical teaching management problems in a targeted manner. Finally, higher vocational colleges should establish a sound supervision and management system, do a good job of specific informatization assessment, formulate corresponding rectification measures, and promote the construction of higher vocational colleges' education and teaching informatization management.

\subsection{Gradually improve the related systems of education and teaching management informatization in vocational colleges}

First of all, higher vocational colleges should clarify the relevant rules and regulations of education and teaching informatization management, establish the specific responsibilities of personnel in various functional departments, and ensure the safety and operability of students and teachers' personal information. Second, it is necessary to realize the effective communication of information among various departments in higher vocational colleges, unify the format and 
content of data information, ensure the sharing of information and data resources, and improve the efficiency of information management in the school. Third, the internal information management system of higher vocational colleges should be connected with higher-level education information management departments to exchange information on campus with national education information, and effectively build a perfect confidence transmission and sharing mechanism.

\subsection{Comprehensively improve the personalization and practicality of education and teaching data and information in higher vocational colleges}

The effective implementation of education and teaching management informatization in higher vocational colleges requires individualization and practicability. First of all, higher vocational colleges need to carry out personalized management design according to their own teaching characteristics, with clear key points, content regulations, and close to reality in the content, so that specific information work can be more efficient. Secondly, higher vocational colleges should carry out personalized data push according to the specific needs of students of different majors, which can not only save the time of students and teachers, but also better implement management measures. Third, it is possible to analyze and calculate the learning habits of students and teachers based on cloud computing and big data, dig deeper into the content of the data, and develop more practical software functions for education and teaching management, and listen to the opinions of teachers and students in a timely manner. Update and adjust to ensure that the entire information management system better serves students and teachers.

\section{Concluding remarks}

The informatization of education and teaching management in higher vocational colleges is a process of continuous updating. Schools should change traditional information management concepts, attach importance to the application of new technologies, and use the support of cloud computing and big data technology to better realize the informatization of education and teaching management Personalized services make students' learning and teachers' teaching more efficient, build a complete information management system, effectively improve the quality of education and teaching information management in higher vocational colleges, and cultivate more excellent compound professionals for the society.

\section{References}

1. Tan Zheng, Sun Zeyu. Informatization strategy of university education and teaching management in the era of cloud computing and big data[J]. Enterprise Technology and Development, 2018, 000(010):149-150.

2. Li Lin. Informatization strategy of university education and teaching management in the era of cloud computing and big data[J]. Digital Design (Part 1), 2018, 000(004): 120.

3. Chang Rui, Zhang Nan, Huang Jieqiong. Informatization strategy of college education and teaching management in the era of cloud computing and big data[J]. Contemporary Tourism, 2019(12). 